\title{
CCL25 wt Allele
}

National Cancer Institute

\section{Source}

National Cancer Institute. CCL25 wt Allele. NCI Thesaurus. Code C49742.

Human CCL25 wild-type allele is located in the vicinity of 19p13.2 and is approximately 10 $\mathrm{kb}$ in length. This allele, which encodes which encodes C-C motif chemokine 25 protein, plays a role in the chemotaxis of thymocytes, activated macrophages, THP-1 cells, and dendritic cells involved in inflammatory processes. 